\title{
Faktor Penentu Berkembangnya Wisata Alam Air Terjun Coban Canggu Pacet Kabupaten Mojokerto
}

\author{
Rasy Febrian Gustin dan Arwi Yudhi Koswara \\ Departemen Perencanaan Wilayah dan Kota, Fakultas Arsitektur, Desain dan Perencanaan \\ Institut Teknologi Sepuluh Nopember (ITS) \\ e-mail: arwiyudhi@gmail.com
}

\begin{abstract}
Abstrak - Pada tahun 2014 jumlah pengunjung Air terjun Coban Canggu mencapai 463.275 pengunjung, pada tahun 2015 jumlah pengunjung mengalami peningkatan menjadi 617.712 pengunjung (DISPORABUDPAR Kabupaten Mojokerto), namun kondisi eksisting yang ada menunjukkan bahwa wisata alam Coban Canggu ini belum optimal pengembangannya, sehingga penelitian ini bertujuan untuk merumuskan arahan pengembangan wisata alam air terjun Coban Canggu di Kecamatan Pacet. Sasaran penelitian ini adalah menganalisa faktor penentu berkembangnya wisata alam air terjun Coban Canggu menggunakan analisis. Berdasarkan hasil penelitian karakteristik wisata alam Coban Canggu didukung oleh keberadaan Daya Tarik Wisata berupa air terjun dengan kolam airnnya, akses jalan, dan kesejahteraan masyarakat dari kegiatan wisata ini. Selanjutnya didapatkan faktor yang mendukung pengembangan wisata air Coban Cangu Pacet adalah keberadaan Daya Tarik Wisata, Aksesibilitas, Fasilitias Pariwisata, Kesejahteraan masyarakat, Infrastruktur, Kepuasan Wisatawan dan Keterpaduan dengan lingkungan.
\end{abstract}

Kata kunci-faktor pengembangan, pariwisata alam, Wisata Air Terjun, Coban Canggu Pacet.

\section{PENDAHULUAN}

$\mathrm{P}$ ARIWISATA adalah suatu perjalanan yang dilakukan orang untuk sementara waktu, yang diselenggarakan dari suatu tempat ke tempat lain meninggalakan tempatnya semula, dengan suatu perencanaan dan dengan maksud bukan untuk berusaha atau mencari nafkah di tempat yang dikunjungi

Potensi dasar pariwisata Kabupaten Mojokerto adalah banyaknya keindahan alam dan lokasi bersejarah yang dapat dijadikan sumber penghasilan untuk daerah. Menurut data dari Dinas Pendapatan Kabupaten Mojokerto sumbangan PDRB dari sektor pariwisata tahun 2012 berjumlah $0,1 \%$ dari 23,6 Triliyun total PDRB Kabupaten Mojokerto [1]. Dilihat dari data tersebut ini disebabkan oleh pengembangan pariwisata yang tidak optimal sehingga berdampak kecilnya kontribusi sektor pariwisata terhadap PDRB Kabupaten Mojokerto. Peruntukan rencana untuk masa yang akan datang Kecamatan Pacet memang di rencanakan untuk menjadi kawasan pariwisata [2]. Hasil survey primer dilokasi pengelolaan wisata alam air terjun Coban Canggu menunjukan keterlambatan, "Untuk perkembangan wisata alam air terjun Coban Cangu itu lambat mas, bisa dibilang terlambat ketimbang tempat wisata lain yang terdekat seperti pemandian air panas Padusan Pacet dan pemandian Ubalan. Karena di Coban Canggu sepi pengunjung menyebabkan perkembangannya terlambat mas. Soalnya kita membangun (mengembangkan) lokasi wisata alam menggunakan uang dari penjualan tiket." Dari jawaban pak Jono dapat disimpulkan bahwa perkembangan wisata alam air terjun Coban Canggu bisa dikatakan tertinggal karena dapat dilihat dari jumlah kunjungan dibandingkan dengan wisata alam disekitarnya. Dengan kondisi rencana yang sudah ada namun belum terealisasi di pengembangan wisata alam di Kecamatan Pacet, diperlukan penelitian pengembangan wisata alam dilokasi ini.

Selain itu, lokasi wisata alam air terjun Coban Canggu di Kecamatan Pacet relatif dekat Pusat Kabupaten Mojokerto menjadi potensial sebagai tujuan pariwisata alternatif di Kabupaten Mojokerto. Sesuai dengan karakteristik bentang alam, Kabupaten Mojokerto memiliki dua karakteristik lingkungan/bentang alam antara lain; landscape dataran rendah, dan landscape gunung/pegunungan, air terjun Coban Canggu salah satunya.

Peningkatan kunjungan wisata alam air terjun Coban Canggu ini sendiri dari tahun 2008 - 2013 telah mencapai 386.063 pengunjung. Pada tahun 2014 jumlah pengunjung mencapai 463.275 jiwa pengunjung. Dari tahun 2014 hingga 2015 data pengunjung masih mengalami peningkatan menjadi 617.712 pengunjung. Hal ini menjunjukan dari segi kunjungan wisatawan Coban Canggu cukup besar.

Otto Soemarwoto (1993:134) menyatakan bahwa pengembangan pariwisata merupakan kegiatan yang kompleks, menyangkut wisatawan, kegiatan, sarana parasarana, objek dan daya tarik, fasilitas penunjang, sarana lingkungan, dan sebagainya. Oleh karena itu dalam pengembangan pariwisata perlu memperhatikan tata letak peruntukan dalam rangka menghindari benturan antara kepentingan pariwisata dengan kepentingan pencagaran. Hal ini dapat terwujud melalui arahan strategi yang baik sehingga keanekaragaman dapat terpelihara dan wisatawan dapat memilih rekreasi yang baik. Berdasarkan survei eksisting pada tahun 2017 kegiatan pariwisata di air terjun Coban Canggu ini masih belum lengkap, meskipun pengunjung meningkat setiap tahunnya naik tapi dalam perkembangan wisata alam ini terkesan lambat karena kondisi infrastruktur dan pelayanan tidak meningkat sehingga pengunjung yang sudah pernah kesana cenderumg enggan untuk kembali dan kebanyakan pengunjung yang datang cenderung wisatawan yang belum pernah berkegiatan pariwisata di wisata alam air terjun coban canggu pacet ini. Dengan kondisi Coban Canggu yang sesuai rencana kecamatan pacet yaitu dijadikan pusat kegiatan pariwisata 
perlu diteliti : faktor penentu berkembangnya wisata alam air terjun Coban Canggu di Kecamatan Pacet.

\section{A. Tujuan Penelitian.}

Tujuan yang ingin dicapai dalam penelitian ini adalah merumuskan faktor penentu berkembangnya wisata alam air terjun Coban Canggu di Kecamatan Pacet.

Sasaran dalam penelitian yang digunakan untuk mencapai tujuan penelitian ini adalah sebagai berikut:

1. Mengidentifikasi karekteristik wisata alam air terjun Coban Canggu di Kecamatan Pacet.

2. Merumuskan faktor penentu berkembangnya wisata alam air terjun Coban Canggu di Kecamatan Pacet.

\section{B. Ruang lingkup}

\section{1) Ruang lingkup Pembahasan}

Lingkup pembahasan dalam penelitian mencakup halhal yang berkaitan dengan pengembangan kawasan pariwisata di Kecamatan Pacet untuk meningkatkan minat pengunjung untuk datang ke lokasi wisata alam air terjun Coban Canggu yang ada di Kecamatan Pacet. Serta mengidentifikasi komponen yang tepat untuk mengembangkan pariwisata dari ekonomi, fisik, dan lingkungan.

2) Ruang lingkup Wilayah

Ruang lingkup wilayah penelitian ini yaitu berada di Pacet, Kabupaten Mojokerto, yang mempunyai batasbatas sebagai berikut:

Sebelah Utara : Kecamatan Kutorejo, Kabupaten Mojokerto

Sebelah Timur : Kecamatan Trawas, Kabupaten Mojokerto

Sebelah Selatan : Kecamatan Bumiaji, Kota Batu Sebelah Barat : Kecamatan Gondang, Kabupaten Mojokerto.

\section{3) Ruang lingkup Substansi}

Ruang lingkup substansi pada penelitian ini meliputi batasan materi penelitian yang berhubungan dengan pengembangan wisata alam air terjun Coban Canggu di Kecamatan Pacet, serta komponen komponen yang berpengaruh dalam pengembangan wisata alam.

\section{TINJAUAN PUSTAKA}

\section{A. Pariwisata}

Definisi tentang kepariwisataan menurut [3], yakni gabungan beberapa kegiatan yang berlangsung berkaitan dengan kedatangan, tinggal dan kegiatan pendatang di daerah tertentu. Dilanjutkan pula pendapat Kurt Morgenroth dalam [3] yang mengatakan bahwa pariwisata adalah kegiatan lalu-lintas orang-orang yang meninggalkan tempat kediamannya untuk sementara waktu, untuk memenuhi kebutuhan hidup.

Definisi lain kepariwisataan menurut World Tourism Organization (WTO) yakni, kegiatan yang terdiri dari aktifitas- aktifitas seseorang yang melakukan perjalanan dan menetap di suatu tempat di luar lingkungannya selama tidak lebih dari satu tahun berturut-turut dan memiliki tujuan.

Pengertian pariwisata menurut [4] yakni kegiatan kemanusiaan berupa hubungan kemanusiaan antar-orang dari daerah geografis yang terbatas, dan didalamnya termasuk tinggal untuk sementara waktu di daerah lain untuk memenuhi berbagai kebutuhan kecuali kegiatan untuk memperoleh penghasilan

Sedangkan menurut Peraturan Pemerintah Republik Indonesia No 50 Tahun 2011 tentang Rencana Induk Pembangunan Kepariwisataan Nasional tahun 2010-2025, menjelaskan definisi kepariwisataan yaitu keseluruhan kegiatan yang terkait dengan pariwisata dan bersifat multidemensi serta multidisiplin yang muncul sebagai wujud kebutuhan setiap orang dan masyarakat setempat, sesama wisatawan, Pemerintah, Pemerintah Daerah, dan pengusaha.

Dari pembahasan klasifikasi jenis pariwisata yang dijabarkan menurut beberapa pakar. Memiliki beberapa kemiripan maksud dan arti, sehingga dapat saling melengkapi satu sama lain untuk mendukung sebuah penlitian. Jenis- jenis kegiatan pariwisata menurut pakar diatas dapat disederhanakan pada tabel berikut

Tabel 1.

Pengertian Pariwisata Sumber Teori

\begin{tabular}{lcl}
\hline \multicolumn{1}{c}{ Yoeti (2008) } & $\begin{array}{l}\text { World Tourism } \\
\text { Organization } \\
\text { (WTO) }\end{array}$ & Wahab (1976) $\begin{array}{l}\text { PP No } 50 \text { tahun } \\
2011\end{array}$ \\
\hline - Kegiatan Wisata & - Kegiatan & \\
- Lalu Lintas & Pariwisata & Kegiatan \\
- Integrasi & & Penunjang \\
- Wisatawan & & Pariwisata \\
- Travel Experience & & \\
& & \\
& & Pasilitas \\
& Pariwisata & \\
\hline \hline
\end{tabular}

\section{B. Komponen Pariwisata}

Menurut [5], komponen pariwisata yang harus ada terdiri dari :

1) Daya Tarik Wisata

Daya tarik wisata merupakan komponen yang menjadi faktor penyebab/pemicu pariwisata, menjadi magnet suatu daerah. Daya tarik wisata adalah salah satu komponen utama pariwisata, yang dapat berupa objek alami maupun buatan.

2) Transportasi

Salah satu ciri utama kegiatan wisata adalah melakukan perjalanan, sehingga tanpa pelayanan jasa perangkutan maka kepariwisataan akan lumpuh. Perangkutan menjadi sangat vital sebagai prasyarat, faktor dominan dan pembentuk jaringan kepariwisataan yang merupakan urat nadi kehidupan kepariwisataan. Kelebihan angkutan yakni meningkatkan daya jelajah para wisatawan terhadap destinasi wisata.

3) Fasilitas dan pelayanan

Akomodasi adalah mata rantai kegiatan wisata, seperti perhotelan, restaurant, lembaga keuangan, transportasi. Keseluruhan tersebut termasuk dalam komponen penunjang kegiatan kepariwisataan.

4) Informasi dan promosi

Daya tarik wisata yang memiliki informasi lengkap dan promosi yang baik akan sangat membantu dalam penyebaran potensi wisata yang dimiliki suatu daerah. Salah satu ekomponen ini merupankan penunjang dalam kegiatan kepariwisataan.

5) Orang sebagai pelaku /wisatawan 
Wisatawan adalah orang yang melakukan kegiatan wisata. Wisatawan dikategorikan menjadi 2 (dua) yakni; wisatawan mancanegara, yaitu wisatawan yang berkunjung atau melakukan kegiatan wisata ke wilayah Negara lain yang bukan merupakan negara dimana dia tinggal, sedangkan wisatawan nusantara, yaitu wisatawan yang melakukan kegiatan wisata di dalam wilayah negaranya sendiri. Selain itu perilaku wisatawan yang mendukung pengembangan lokasi wisata alam tersebut juga dibutuhkan.

Menurut Intosh (1995) [6] menjelaskan bahwa komponen pariwisata selain daya tarik wisata, aksesibilitas dan promosi terdapat pula tambahan, yaitu :

a) Sumber daya alam, merupakan dasar dari sediaan yang dapat dinikmati dan dgunakan oleh wisatawan (objek dan daya tarik wisata)

b) Infrastruktur, seperti penyediaan air bersih, jaringan perangkutan, drainase, pusat pengelolaan limbah.

c) Moda transportasi, termasuk system perangkutan dan fasilitas pendukungnya.

d) Partisipasi masyarakat, yang merupakan bentuk penerimaan masyarakat dan kenyamanan (hospitality service) yang ditawarkan oleh tuan rumah.

Sedangkan menurut Musenaf (1996) [7], yang termasuk dalam komponen suatu kawasan wisata meliputi :

a) Kemudahan pencapaian (aksesibilitas), yakni suatu kondisi atau keadaan tentang kemudahan suatu lokasi wisata yang dapat dicapai wisatawan dari tempat asalnya.

b) Potensi pasar, keberhasilan pengembangan objek dan daya tarik wisata ditentukan oleh tinggi rendahnya potensi pasar atau wisatawan yang akan mengunjungi objek tersebut.

c) Kondisi lingkungan pada dasarnya bersifat timbal balik, seperti pengaruh wisatawan terhadap lingkungan suatu objek hanya dapat dilakukan melalui AMDAL, seperti keamanan, kesehatan.

d) Prasarana dasar, yakni prasarana yang mutlak bagi pengembangan objek dan daya tarik wisata. Unsurunsur tersebut meliputi prasarana jalan, listrik, air bersih, serta telekomunikasi.

e) Pengelolaan/pengusahaan, yakni mengelola sumber daya tarik wisata dan sarana prasarana wisata yang dilakukan oleh steakholder.

f)Sarana wisata, merupakan poin yang menentukan perkembangan objek dan daya tarik wisata yakni akomodasi jumlah hotel, restaurant.

g) Daya tarik pendukung sangat diperlukan dalam pembangunan dan pengembangan objek dan daya Tarik wisata, sehingga wisatawan akan puas karena menyaksikan beberapa daya tarik wisata.

Dari pembahasan komponen-komponen pariwisata yang telah dijabarkan menurut beberapa pakar memiliki kemiripan maksud dan arti, sehingga dapat saling melengkapi satu sama lain. Komponen kegiatan pariwisata disederhanakan pada tabel.

Tabel 2.

Komponen Pariwisata

Sumber Teori

\begin{tabular}{lll}
$\begin{array}{l}\text { Warpani } \\
(2007)\end{array}$ & Intosh (1995) & Musenaf (1995) \\
\hline
\end{tabular}

\begin{tabular}{lll}
\hline - dtw & - Sumber daya alam & $\bullet$ Aksesibilitas \\
- Transpotasi & $\bullet$ Infrastruktur & $\bullet$ Potensi pasar \\
- Fasilitas dan & $\bullet$ Moda transportasi & $\bullet$ Kondisi lingkungan \\
Pelayanan & • Partisipasi & - Prasarana dasar \\
- Informasi dan & masyarakat & $\bullet$ Pengelolaan/pengusahaa \\
promosi & & $\mathrm{n}$ \\
- Wisatawan & & - Daya tarik pendukung
\end{tabular}

Berdasarkan hasil penentuan kriteria diatas, maka bisa disimpulkan bahwa dalam penelitian ini yang akan digunakan sebagai kriteria dan variabel adalah sebagai berikut:

Tabel 3.

Kriteria dan Variabel Penelitian

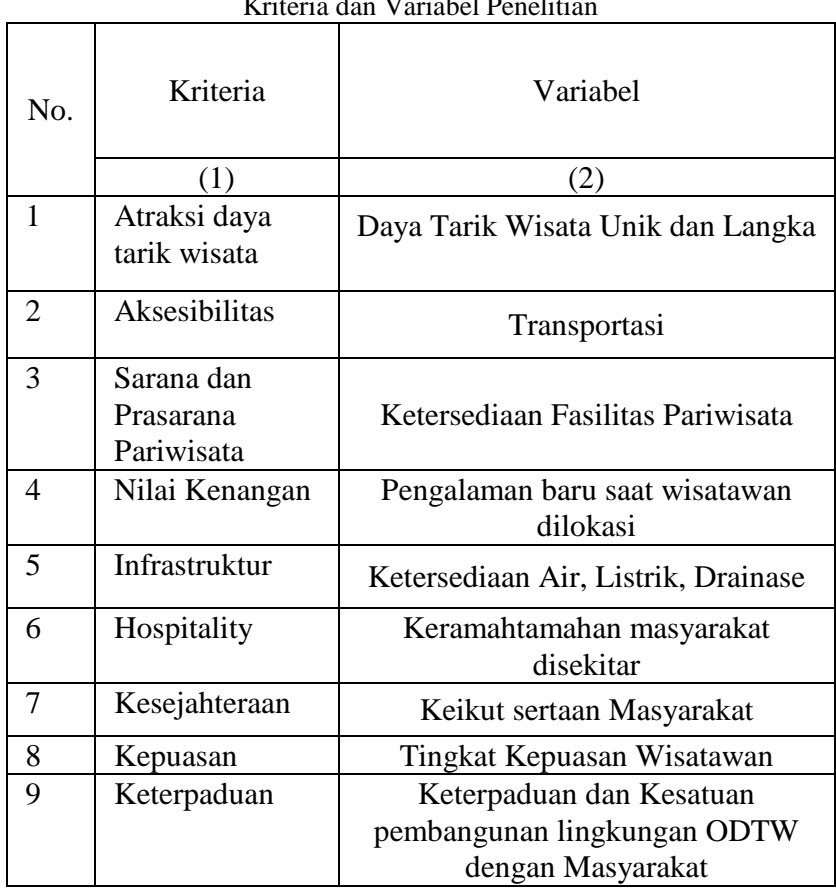

\section{METODE PENELITIAN}

\section{A. Teknik Pengumpulan Data}

Dalam pengumpulan data, teknik yang digunakan adalah survei data primer dan sekunder. Data sekunder yang dikumpulkan bersumber dari dokumen-dokumen yang dimiliki oleh berbagai instansi, meliputi: Badan Perencanaan dan Pembangunan Daerah (Bappeda) Kabupaten Mojokerto, bagian Fisik, Dinas Cipta Karya Kabupaten Mojokerto, Dinas Kebudayaan dan Pariwisata Kabupaten Mojokerto, dan instansi lainnya. Metode-metode yang digunakan dalam pengumpulan data untuk penelitian ini adalah sebagai berikut:

\section{1) Metode Pengumpulan Data Primer}

Survei primer dalam penelitian ini adalah pengumpulan data dengan melakukan pengamatan secara langsung (observasi lapangan), wawancara, serta kuesioner.Survei primer yang dilakukan bertujuan untuk mendapatkan gambaran kondisi lingkungan dan perubahanperubahan/fenomena yang terjadi melalui pengamatan suatu fakta menggunakan indera, tanpa harus mengambil sampel. Survei data primer terdiri atas : 
a. Observasi

b. Kuisioner

2) Metode Pengumpulan Data Sekunder

Metode pengumpulan data sekunder merupakan pengumpulan data, informasi dan peta kepada sejumlah instansi dan literatur terkait. Pengumpulan data sekunder terdiri atas:

a. Survei Instansi

b. Survei Literatul

\section{B. Metode Analisis Data}

Metode analisis digunakan untuk mengolah data yang diperoleh dari hasil survey primer dan sekunder untuk mencapai tujuan penelitian. Analisis digunakan untuk memberikan pemahaman yang luas akan suatu konsep yang akan dijalankan. Disamping itu juga membantu dalam memberikan pilihan terbaik dari kondisi nyata yang ada. Secara garis besar, proses analisis dilakukan dengan 3 tahap, antara lain:

Tabel 4.

Keterkaitan antara Sasaran dan Analisa

\begin{tabular}{llll}
\hline \hline No & \multicolumn{1}{c}{ Sasaran } & Teknik Analisis & \multicolumn{1}{c}{ Hasil Analisis } \\
\hline 1. & Menganalisa faktor & Delphi & Faktor yang menjadi \\
& penentu & & penentu dalam \\
& berkembangnya & pengembangan \\
& Wisata Alam air terjun & Wisata Alam air \\
Coban Canggu di & terjun Coban \\
Kecamatan Pacet & Canggu di
\end{tabular}

Kecamatan Pacet

\section{1) Menganalisa Faktor Penentu Berkembangnya Wisata Alam Air Terjun Coban Canggu di Kecamatan Pacet}

Dasar-dasar dalam teknik Delphi adalah latihan komunikasi kelompok di antara ahli-ahli yang tersebar secara geografis. Metode ini membuat para ahli dapat menyepakati keputusan secara sistematis dengan permasalahan yang sangat kompleks. Esensi utama dari teknik ini hampir fokus pada permasalahan. Metode ini menggunakan media kuisoner yang didesain agar dapat memunculkan atau mengembangkan respon individu terhadap sebuah permasalahan dan me-review pendapat dari beberapa pakar atau ahli mengenai permasalahan yang telah ditetapkan. Pada dasarnya, metode Delphi digunakan untuk menyelesaikan kekurangan dari aksi atau kegiatan komite yang konvensional, seperti pertemuan dan rapat-rapat yang menyulitkan.

Pada proses analisa delphi merupakan tahap untuk memperoleh konsensus terhadap suatu grup yang dilakukan secara kontinu sampai memperoleh kesamaan opini terhadap suatu faktor. Pada tahap ini dilakukan analisis terhadap faktor-faktor yang mempengaruhi pengembangan sektor pariwisata yang dihasilkan dari wawancara pada reponden/ narasumber terkait. Faktor-faktor yang telah diperoleh dari tinjauan kebijakan/ tinjuan pustaka akan ditanyakan kepada responden secara berulang sehingga menyisakan beberapa faktor yang benar-benar memiliki pengaruh atau bisa disebut sebagai literasi faktor.

\section{ANALISA DAN PEMBAHASAN}

A. Identifikasi Karakteristik Wisata Alam Air Terjun Coban Canggu di Kecamatan Pacet

Dalam melakukan analisa ini menggunakan input pada variabel-variabel yang didapatkan dari tinjauan pustaka dan disesuaikan dengan indikator penelitian. Analisa yang digunakan adalah Theoritycal Descriptive Kualitatif. Analisis ini digunakan untuk memberikan gambaran mengenai objek studi yang menjadi fokus penelitian dan mengubah variable penelitian menjadi kriteria yang lebih spesifik dengan cara mendeskripsikan pengaruh variabel tersebut terhadap tujuan penelitian.

Hasil dari Analisis deskriptif kualitatif untuk mengetahui karakteristik wisata alam air terjun Coban Canggu antara lain:

1. Dengan memiliki daya tarik yang berada di kaki gunung welirang dan dibawahnya juga terdapat kolam penampungan air yang jatuh dari coban canggu menjadikan daya tarik tersendiri pada wisata daerah Pacet.

2. Dengan adanya daya tarik wisata di air terjun coban canggu, maka perlu penunjang aktivitas di dalamnya. Diantaranya fasilitas transportasi. Dengan adanya moda transportasi memudahkan pengunjung untuk berkunjung ke tempat wisata tersebut. Seperti penambahan trayek angkutan umum.

3. Fasilitas yang terdapat pada obyek wisata tersebut, masih perlu adanya penambahan. Seperti adanya "Food Court". Selain ada penambahan fasilitas, juga perlu pemeliharaan fasilitas yang sudah tersedia. Selain itu faktor penerangan atau jaringan listrik merupakan hal yang penting bagi pengembangan tempat wisata ini.

4. Dengan keindahan alam yang dimiliki air terjun canggu, perlu adanya kegiatan yang bersifat berkelanjutan. Kegiatan yang yang dilangsungkan secara berkala. Selain itu dengan masih terjaganya ekosistem pada obyek wisata ini, juga perlu adanya edukasi pada masyarakat dan pengunjung dalam menjaga kebersihan dan keindahan obyek wisata. Seperti adanya kegiatan kebersihan maupun penyediaan fasilitas kebersihan yang memadahi.

5. Ketersediaan Air, Listrik, dan Drainase sangat mendukung untuk pengembangan lokasi wisata alam ini.

6. Dengan dukungan masyarakat yang membantu memberikan informasi tentang wisata ini, menumbuhkan rasa saling memiliki dan menjaga obyek wisata air terjun coban canggu.

7. Adanya pengelolaan dan penentuan segala bentuk aktivitas agar tidak menimbulkan kesan yang tidak tertata.

8. Perlu adanya fasilitas penunjang dan kegiatan yang baru pada obyek wisata air terjun coban canggu untuk meningkatkan rasa kepuasan pengunjung. 
9. Perlu adanya kerjasama dalam kepedulian lingkungan antara masyarakat sekitar, pengunjung, serta pemerintah daerah dalam mengelola wisata air terjun coban canggu. Salah satunya seperti pembentukan komunitas peduli lingkungan kawasan wisata.

2) Menganalisa Faktor Penentu Berkembangnya Wisata Alam Air Terjun Coban Canggu di Kecamatan Pacet

Dalam menganalisa faktor penentu berkembangnya wisata alam air terjun Coban Canggu di Kecamatan Pacet ini, dilakukan kajian terkait faktor penentu berkembangnya wisata alam air terjun terlebih dahulu melalui sintesis pustaka lebih lanjut, kemudian akan dilakukan analisis delphi guna melakukan uji validitas terhadap kajian faktor penentu yang telah dilakukan. Berikut merupakan diagram analisis Delphi dan sitesis faktor yang digunakan sebagai penentu berkembangnya wisata alam air terjun Coban Canggu di Kecamatan Pacet, Kabupaten Mojokerto.

Tabel 5.

Analisis Delphi Tahap I

\begin{tabular}{|c|c|c|c|c|c|c|c|}
\hline & & isis Delphi Tahap & & & & & \\
\hline \multirow[t]{2}{*}{ No } & \multirow[t]{2}{*}{ Variabel } & \multirow[t]{2}{*}{ Faktor } & \multicolumn{5}{|c|}{ Responden } \\
\hline & & & 1 & $\begin{array}{l}\mathrm{R} \\
2\end{array}$ & $\begin{array}{l}\mathrm{R} \\
3\end{array}$ & $\begin{array}{l}\mathrm{R} \\
4\end{array}$ & $\begin{array}{l}\mathrm{R} \\
5\end{array}$ \\
\hline 1 & $\begin{array}{l}\text { Objek Daya Tarik } \\
\text { Wisata Unik dan } \\
\text { Langka }\end{array}$ & Atraksi Alam & $S$ & $S$ & $S$ & $\mathrm{~S}$ & $S$ \\
\hline 2 & Transportasi & Moda Transportasi & $S$ & $S$ & S & $S$ & $\mathrm{~S}$ \\
\hline 3 & $\begin{array}{l}\text { Ketersediaan Fasilitas } \\
\text { Pariwisata }\end{array}$ & Tempat Makan & $S$ & $S$ & $\begin{array}{l}\mathrm{T} \\
\mathrm{S}\end{array}$ & $S$ & $\bar{S}$ \\
\hline 4 & $\begin{array}{l}\text { Pengalaman Baru } \\
\text { saat Wisatawan di } \\
\text { lokasi }\end{array}$ & Aktifitas Baru & S & S & S & S & $\begin{array}{l}\mathrm{T} \\
\mathrm{S}\end{array}$ \\
\hline 5 & $\begin{array}{l}\text { Ketersediaan Air, } \\
\text { Listrik, dan Drainase }\end{array}$ & Listrik dan drainase & $S$ & $S$ & $S$ & $\mathrm{~S}$ & $S$ \\
\hline 6 & $\begin{array}{l}\text { Keramahtamahan } \\
\text { masyarakat disekitar }\end{array}$ & $\begin{array}{l}\text { Keterbukaan } \\
\text { informasi oleh } \\
\text { masyarakat di } \\
\text { warung }\end{array}$ & S & $S$ & S & $S$ & $S$ \\
\hline 7 & $\begin{array}{l}\text { Keikut sertaan } \\
\text { Masyarakat }\end{array}$ & $\begin{array}{l}\text { Keterlibatan } \\
\text { dikegiatan } \\
\text { pariwisata }\end{array}$ & $S$ & S & $S$ & $S$ & $S$ \\
\hline 8 & $\begin{array}{l}\text { Tingkat Kepuasan } \\
\text { Wisatawan }\end{array}$ & $\begin{array}{l}\text { Kegiatan repetisi } \\
\text { kunjungan }\end{array}$ & $S$ & $S$ & $S$ & $S$ & $\begin{array}{l}\mathrm{T} \\
\mathrm{S}\end{array}$ \\
\hline 9 & $\begin{array}{l}\text { Keterpaduan dan } \\
\text { Kesatuan } \\
\text { pembangunan } \\
\text { lingkungan ODTW } \\
\text { dengan Masyarakat }\end{array}$ & $\begin{array}{l}\text { Dukungan alam } \\
\text { sesuai untuk } \\
\text { pariwisata }\end{array}$ & $S$ & $S$ & $S$ & $\mathrm{~T}$ & $S$ \\
\hline
\end{tabular}

Menurut hasil dari analisis delphi tahap 1 ini terdapat responden yang kurang setuju terhadap beberapa variabel yang telah ditanyakan kepada mereka, sehingga perlu adanya analisa delphi tahap 2 supaya bisa mencapai konsensus untuk analisa faktor penentu berkembangnya wisata alam air terjun Coban Canggu Pacet.

Tabel 6.

Analisis Delphi Tahap II

\begin{tabular}{|c|c|c|c|c|c|c|c|}
\hline \multirow[t]{2}{*}{ no } & \multirow[t]{2}{*}{ Variabel } & \multirow[t]{2}{*}{ Faktor } & \multicolumn{5}{|c|}{ Responden } \\
\hline & & & $\mathrm{R}$ & $\mathrm{R}$ & $\begin{array}{l}\mathrm{R} \\
3\end{array}$ & 4 & $\begin{array}{l}\mathrm{R} \\
5\end{array}$ \\
\hline 1 & $\begin{array}{l}\text { Ketersediaan } \\
\text { Fasilitas } \\
\text { Pariwisata }\end{array}$ & $\begin{array}{l}\text { Tempat } \\
\text { Makan }\end{array}$ & $\mathrm{S}$ & $\mathrm{S}$ & $\mathrm{S}$ & $S$ & $\mathrm{~S}$ \\
\hline 2 & $\begin{array}{l}\text { Keramahtam } \\
\text { ahan } \\
\text { masyarakat } \\
\text { disekitar }\end{array}$ & $\begin{array}{l}\text { Keterbukaa } \\
\text { n informasi } \\
\text { oleh } \\
\text { masyarakat } \\
\text { di warung }\end{array}$ & S & S & $\begin{array}{l}\mathrm{T} \\
\mathrm{S}\end{array}$ & S & $\begin{array}{l}\mathrm{T} \\
\mathrm{S}\end{array}$ \\
\hline 3 & $\begin{array}{l}\text { Keikut } \\
\text { sertaan } \\
\text { Masyarakat }\end{array}$ & $\begin{array}{l}\text { Keterlibatan } \\
\text { dikegiatan } \\
\text { pariwisata }\end{array}$ & $\mathrm{S}$ & $\mathrm{S}$ & $S$ & $\mathrm{~S}$ & $\mathrm{~S}$ \\
\hline 4 & $\begin{array}{l}\text { Tingkat } \\
\text { Kepuasan } \\
\text { Wisatawan }\end{array}$ & $\begin{array}{l}\text { Kegiatan } \\
\text { repetisi } \\
\text { kunjungan }\end{array}$ & $\mathrm{S}$ & $\mathrm{S}$ & $S$ & S & $\mathrm{S}$ \\
\hline 5 & $\begin{array}{l}\text { Keterpaduan } \\
\text { dan } \\
\text { Kesatuan } \\
\text { pembanguna } \\
\text { n lingkungan } \\
\text { ODTW } \\
\text { dengan } \\
\text { Masyarakat }\end{array}$ & $\begin{array}{l}\text { Dukungan } \\
\text { alam sesuai } \\
\text { untuk } \\
\text { pariwisata }\end{array}$ & $\mathrm{S}$ & $\mathrm{S}$ & $\mathrm{S}$ & $S$ & $\mathrm{~S}$ \\
\hline
\end{tabular}

Dari hasil analisis delphi tahap 2 bertujuan untuk mencapai konsensus dihasilkan bahwa faktor dukungan alam sesuai untuk pariwisata merupakan salah satu faktor yang sangat penting dalam pengembangan wisata alam air terjun Coban Canggu. Faktor tersebut merupakan kunci utama dalam pengembangan pariwisata alam karena jika daerah yang ditujukan sebagai salam satu pengembangan pariwisata alam ini tidak memiliki faktor tersebut maka tidak akan ada daya tarik wisata yang dapat dijual dalam pengembangan pariwisata alam tersebut sehingga bisa dikatakan tidak dapat dijadikan sebagai salah satu kategori pariwisata alam.

Tabel 7.

Hasil Analisis Delphi

NO Variabel Faktor




\begin{tabular}{|c|c|c|}
\hline NO & Variabel & Faktor \\
\hline 2 & Transportasi & Moda Transportasi \\
\hline 3 & $\begin{array}{l}\text { Ketersediaan } \quad \text { Fasilitas } \\
\text { Pariwisata }\end{array}$ & Tempat Makan \\
\hline 4 & $\begin{array}{l}\text { Ketersediaan Air, Listrik, } \\
\text { dan Drainase }\end{array}$ & Listrik dan Drainase \\
\hline 5 & Keikutsertaan Masyarakat & $\begin{array}{l}\text { Keterlibatan dikegiatan } \\
\text { pariwisata }\end{array}$ \\
\hline 6 & $\begin{array}{l}\text { Tingkat Kepuasan } \\
\text { Wisatawan }\end{array}$ & Kegiatan repetisi kunjungan \\
\hline 7 & $\begin{array}{l}\text { Keterpaduan dan Kesatuan } \\
\text { pembangunan lingkungan } \\
\text { ODTW dengan Masyarakat }\end{array}$ & $\begin{array}{l}\text { Dukungan alam sesuai untuk } \\
\text { pariwisata }\end{array}$ \\
\hline
\end{tabular}

Dari hasil delphi diketahui faktor faktor yang berpengaruh dalampengembangan parwisata alam air terjun Coban Cangu Kecamatan Pacet Kabupaten Mojokerjo adalah : keberadaan daya tarik, aksesibilitas keberadaan jalan dan moda transportasi, Ketersediaan Fasilitas Pariwisata, kelengkapan infrastruktur di lokasi air terjun, Keikutsertaan Masyarakat utamanya dikegiatan ekonomi pariwisata, kepuasan wisatawan dan keterpaduan kegiatan wisata dengan lingkungan.

\section{KESIMPULAN DAN REKOMENDASI}

Hasil dari analisis diketahui faktor faktor yang berpengaruh dalampengembangan parwisata alam air terjun Coban Cangu Kecamatan Pacet Kabupaten Mojokerjo adalah: keberadaan daya tarik, aksesibilitas keberadaan jalan dan moda transportasi, Ketersediaan Fasilitas Pariwisata, kelengkapan infrastruktur di lokasi air terjun, Keikutsertaan Masyarakat utamanya dikegiatan ekonomi pariwisata, kepuasan wisatawan dan keterpaduan kegiatan wisata dengan lingkungan.

Saran penelitian ini bisa digunakan untuk Pemerintah Kabupaten Mojokerto.

\section{DAFTAR PUSTAKA}

[1] Peraturan Daerah Kab. Mojokerto No 01 Tahun 2009 tentang Penyelenggaraan Usaha Pariwisata Dan Kebudayaan. 2009.

[2] Rencana Tata Ruang Wilayah Kabupaten Mojokerto Tahun 2012-2032.

[3] O. A. Yoeti, Pengantar Ilmu Pariwisata. Bandung: Angkasa, 1985.

[4] S. Wahab, Tourismn Management. Jakarta: PT Pradnya Paramita, 1997.

[5] S. P. Warpani, Pariwisata dalam Tata Ruang Wilayah. Bandung, 2007.

[6] J. R. B. McIntosh, W., Goeldner, C. R., Ritchie, Tourism: Principles,Practices, Philosophies. New York: John Wiley \& Sons, Inc, 1995.

[7] D. Musenaf, Manajemen usaha pariwisata. Jakarta: PT. Toko Gunung Agung, 1995. 